\title{
Процессы формирования упорядоченных двумерных фаз кремния (пористого силицена) на поверхности g-Si3 $\mathrm{N}_{3} / \mathrm{Si}(111)$
}

\author{
В.Г. Мансуров ${ }^{1}$, Ю.Г. Галицын ${ }^{1}$, Т.В. Малин ${ }^{1}$, Д.С. Милахин ${ }^{1}$, А.С. Петров ${ }^{1}$, К.С. Журавлев ${ }^{1}$ \\ ${ }^{1}$ Институт физики полупроводников им. А.В.Ржанова, Новосибирск, 630090, пр-т Академика
} Лаврентьева, 13

эл.nочта: mansurov@isp.nsc.ru

DOI $10.34077 /$ RCSP2021-67

Открытие графена, первого термодинамически стабильного двумерного материала, чьи экзотические электронные свойства основаны на безмассовых дираковских электронах, открыло новое направление в материаловедении. Однако повсеместное использование графена сдерживается проблемами интеграции в современные нанотехнологии на основе кремния. Получение кремния в графеноподобной форме, то есть силицена, позволяет решить проблему интеграции в кремниевые технологии, открывая новые и интригующие направления для кремниевой наноэлектроники и фотоники, таких как настраиваемое поглощение для фотоэлектрических приложений, терагерцовые детекторы и эмиттеры, и др. Силицен обычно получают на поверхностях металлов, на которых не образуются силициды, например, таких как серебро, золото, рутений, иридий, однако имеется высокая потребность в синтезе силицена на поверхности кремния.

В данной работе исследовались процессы формирования упорядоченных фаз кремния и возможность синтеза силицена на графеноподобных слоя $\mathrm{g}-\mathrm{Si}_{3} \mathrm{~N}_{3}$ и g-AlN, которые предварительно формировались на поверхности $\mathrm{Si}(111)$, по технологии предложенной нами ранее [1-3].

Эксперименты проводились в сверхвысоковакуумной установке молекулярно-лучевой эпитаксии CBE-32 (Riber, Франция). Кремний наносился из твердотельного источника $\mathrm{Si}$, нагреваемого прямым пропусканием тока, на поверхности слоев $\mathrm{g}-\mathrm{Si}_{3} \mathrm{~N}_{3} / \mathrm{Si}(111)$ со сверхструктурой $(8 \times 8)$ и g-AlN/g$\mathrm{Si}_{3} \mathrm{~N}_{3} / \mathrm{Si}(111)$ со сверхструктурой $(4 \times 4)$. Изменения структуры поверхности в процессе нанесения исследовались с помощью дифракции быстрых электронов ДБЭ. Эволюция дифракционной картины регистрировалась и анализировалась с помощью системы kSA-400 (k-Space Associate, CША).

Было обнаружено, что при экспозиции поверхности $\mathrm{g}-\mathrm{Si}_{3} \mathrm{~N}_{3}$ под потоком кремния при температуре $750{ }^{\circ} \mathrm{C}$ наблюдалось появление новой упорядоченной фазы $(3 \times 3)$, как показано на рисунке 1 . Такая периодичность кремниевого слоя 11.6 А наблюдалась ранее на поверхности серебра и может быть идентифицирована как пористый силицен [4,5].
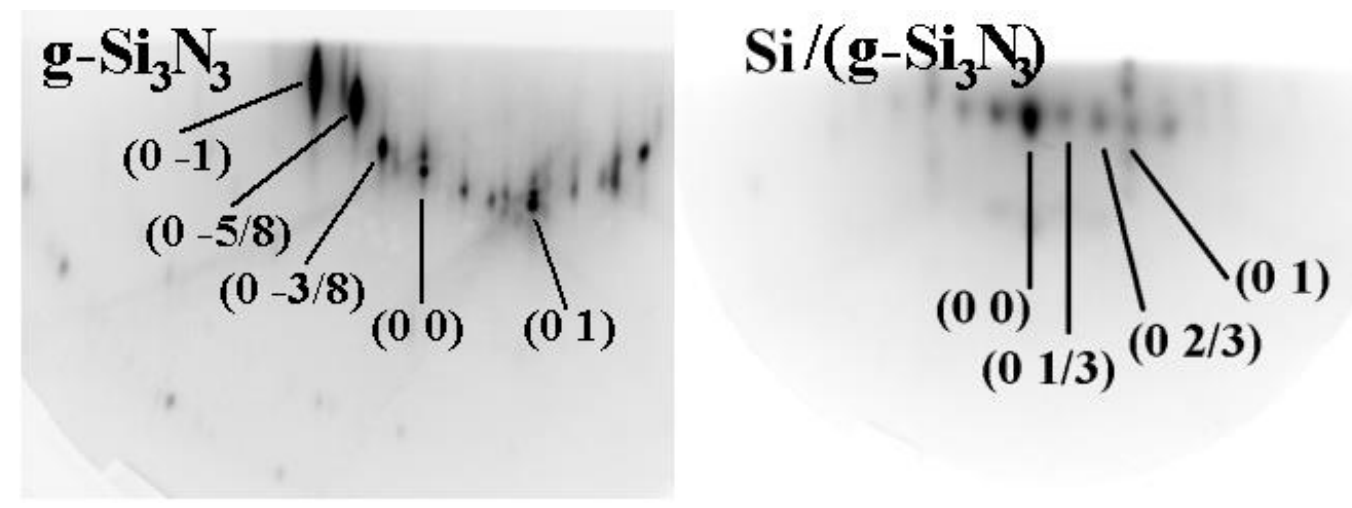

Рис.1. Дифракционные картины исходной поверхности графеноподобной фазы нитрида кремния (8x8) g-Si $\mathrm{N}_{3}$ и после нанесения кремния $(3 \mathrm{x} 3) \mathrm{Si} /\left(\mathrm{g}-\mathrm{Si}_{3} \mathrm{~N}_{3}\right)$ при температуре $750{ }^{\circ} \mathrm{C}$.

Исследование выполнено при финансовой поддержке РФФИ и Правительства Новосибирской области в рамках Проекта № 20-42-540011.

\section{Лumepamypa}

[1] V.G.Mansurov, T.V.Malin, Yu.G Galitsyn, et. al., J. Cryst. Growth, 441 (2016) 12.

[2] V. Mansurov, T.Malin, Yu.Galitsyn, K.Zhuravlev, J. Cryst. Growth, 428 (2015) 93.

[3] V.G. Mansurov et. al., ed. C. Wongchoosuk, IntechOpen, (2019) DOI:10.5772/intechopen.81775.

[4] B. Feng et. al., Nano Letters. 12 (2012) 3507.

[5] G. S. L. Fabris et. al., Theoretical Chemistry Accounts 137 (2018) 13. 